\title{
Regulation of Learning by EphA Receptors: a Protein Targeting Study
}

\author{
R. Gerlai, ${ }^{1}$ N. Shinsky, ${ }^{1}$ A. Shih, ${ }^{1}$ P. Williams, ${ }^{2}$ J. Winer, ${ }^{2}$ M. Armanini, ${ }^{1}$ B. Cairns, ${ }^{3}$ J. Winslow, ${ }^{1}$ W.-Q. Gao, ${ }^{1}$ \\ and H. S. Phillips ${ }^{1}$
}

Genentech, Inc., Departments of ${ }^{1}$ Neuroscience, ${ }^{2}$ Research BioAssay, and ${ }^{3}$ Pathology, South San Francisco, California 94080

EphA family receptor tyrosine kinases and their ephrin-A ligands are involved in patterning axonal connections during brain development, but until now a role for these molecules in the mature brain had not been elucidated. Here, we show that both the EphA5 receptor and its ephrin-A ligands (2 and 5) are expressed in the adult mouse hippocampus, and the EphA5 protein is present in a phosphorylated form. Because there are no pharmacological agents available for EphA receptors, we designed recombinant immunoadhesins that specifically bind to the receptor binding site of the ephrin-A ligand (antagonist) or the ligand binding site of the EphA receptor (agonist) and thus target EphA function. We demonstrate that intrahippocampal infusion of an EphA antagonist immunoadhesin leads to impaired performance in two behavioral paradigms, T-maze spontaneous alternation and context-dependent fear conditioning, sensitive to hippocampal function, whereas activation of EphA by infusion of an agonist immunoadhesin results in enhanced performance on these tasks. Because the two behavioral tasks have different motivational, perceptual, and motor requirements, we infer the changes were not caused by these performance factors but rather to cognitive alterations. We also find bidirectional changes in gene expression and in electrophysiological measures of synaptic efficacy that correlate with the behavioral results. Thus, EphA receptors and their ligands are implicated as mediators of plasticity in the adult mammalian brain.

Key words: EphA tyrosine kinase receptor; immunoadhesin; learning; mouse; hippocampus; inbred strain; LTP
EphA receptors represent the largest subfamily of receptor tyrosine kinases (Friedman and O'Leary, 1996). The ephrin-A ligands interact with EphA receptors to mediate repulsive axonal guidance in patterning the developing nervous system (Drescher et al., 1995; Winslow et al., 1995; Gao et al., 1996; Zhang et al., 1996; Meima et al., 1997; Orioli and Klein, 1997; Zhou, 1997; Flanagan and Vanderhaegen, 1998; Frisén et al., 1998; P. P. Gao et al., 1998). It is not known whether EphA receptors play any role in the adult brain in vivo. In this report, we use in situ hybridization and quantitative (TaqMan) reverse transcription (RT)-PCR to show that both the EphA5 receptor and its ligands, ephrin-A5 and -A2, are expressed in the mature mouse brain. We also investigate whether EphA5 is or can be activated, i.e., phosphorylated, in the adult mouse brain.

EphA receptors were shown to play a role in determining patterns of synapse formation in development (Drescher et al., 1995; Gao et al., 1996; Zhang et al., 1996; Zhou, 1997; Flanagan and Vanderhaegen, 1998; Frisén et al., 1998; P. P. Gao et al., 1998), and recently, these receptors and their ligands were found to have PDZ (postsynaptic density-95/Discs large/zona occludens-1) recognition motifs and to bind to and colocalize with PDZ proteins at synaptic sites of the mammalian neuron in vitro (Torres et al., 1998). Initial evidence for in vitro effects on synaptic plasticity, including long-term potentiation (LTP), has

\footnotetext{
Received March 8, 1999; revised Aug. 20, 1999; accepted Aug. 20, 1999.

We thank Nerrisa Mendoza and Alisha Eisert for technical help; Louis Tamayo and Allison Bruce for figures; Steven Chamow for CD4-IgG; and Ingrid Caras, Nicola Clayton, Wim Crusio, and David Shelton for discussions on earlier versions of this manuscript.

Correspondence should be addressed to R. Gerlai, Mailstop \#72, Room 10-413, 1 DNA Way, South San Francisco, CA 94080. E-mail: gerlai@gene.com.

Copyright (C) 1999 Society for Neuroscience $0270-6474 / 99 / 199538-12 \$ 05.00 / 0$
}

also been obtained (W.-Q. Gao et al., 1998). Given the continued expression of EphA5 and its ligands in the adult brain, these results raise the possibility that EphA receptors are not only involved in embryonic development of the brain but also in synaptic remodeling and plasticity thought to underlie learning and memory (Bliss and Collingridge, 1993). Therefore, we sought to determine whether EphA receptors regulate neuronal function in vivo in the mature brain and, in turn, influence learning.

To target EphA5 function, we use a novel strategy termed protein targeting (Gerlai et al., 1998b) based on in vivo application of recombinant fusion proteins, the immunoadhesins (Chamow and Ashkenazy, 1996). The immunoadhesins used in the present study contain the full native ligand binding domain of the EphA5 receptor (EphA5-IgG) or the receptor binding domain of the ephrin-A5 ligand (ephrinA5-IgG). These immunoadhesins have opposing effects on the receptor: EphA5-IgG, by scavenging the endogenous ligand, acts as an antagonist and ephrinA5-IgG, by dimerizing and initiating the autophosphorylation cycle of the receptor, as an agonist of EphA function (Winslow et al., 1995; Meima et al., 1997).

In the present paper, we focus on the analysis of behavioral changes elicited by intrahippocampal infusion of the EphA antagonist and agonist immunoadhesins and also study potential underlying mechanisms, including gene expression changes and synaptic plasticity. We demonstrate, for the first time, that EphA receptors play a significant role in the adult brain in which they influence cognitive function.

\section{MATERIALS AND METHODS}

Animals and housing. Experimental mice (males) from inbred strains C57BL/6 and DBA/2 were 3-4 months old and were housed in groups of 10 under standard conditions described previously (Gerlai et al., 1998b). 

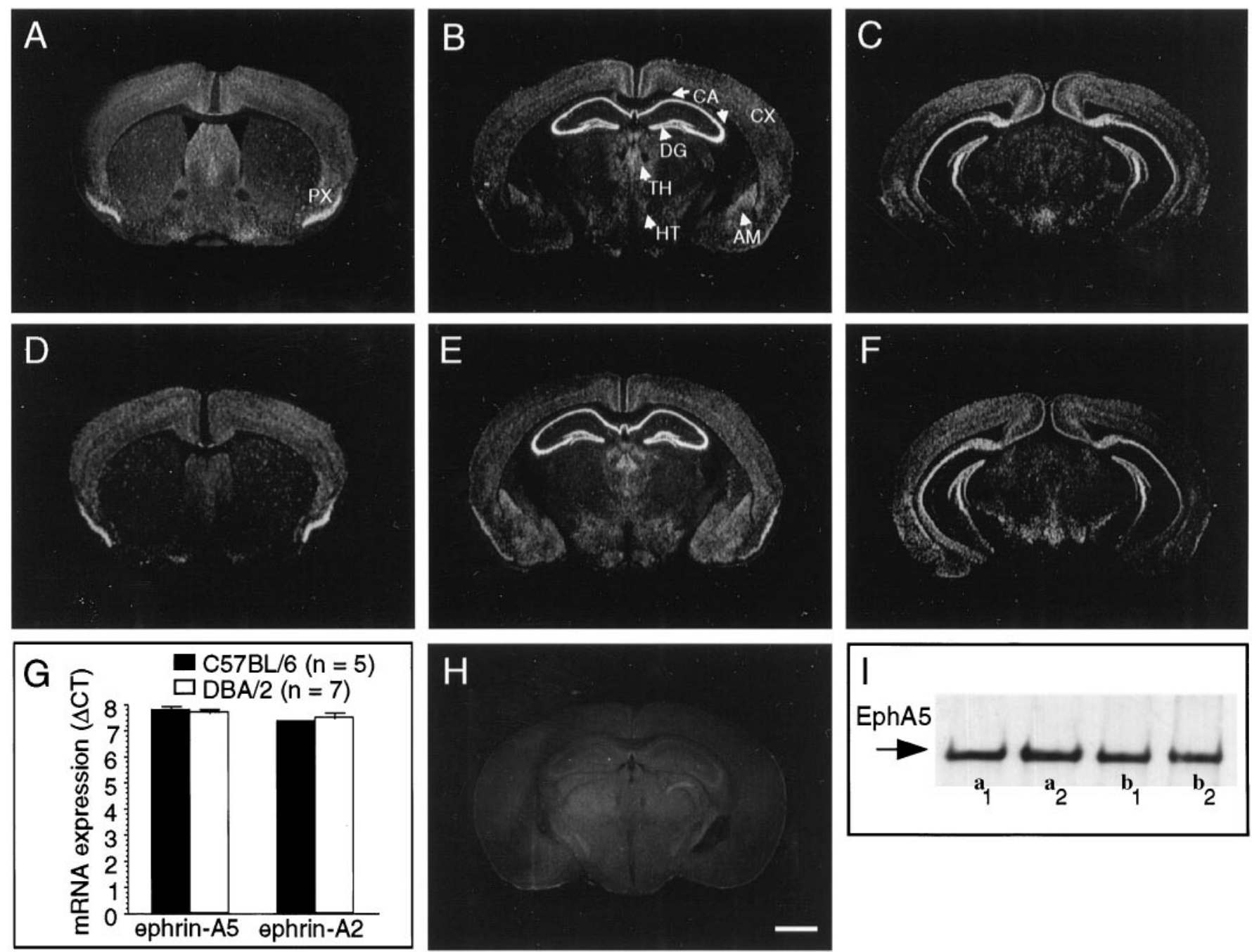

Figure 1. The EphA5 receptor and its ligands are expressed in the adult mouse hippocampus. In situ hybridization (coronal sections with antisense probe) for EphA5 mRNA expression in the brain of C57BL/6 $(A-C)$ and DBA/2 $(D-F)$ strains of mice. A section with sense (control) probe $(H)$ is also shown. Approximate position of sections from bregma are (in mm): $A, D,+0.75 ; B, E, H,-2.10 ; C, F,-3.00$. Both C57BL6 and DBA/2 mice display prominent expression of EphA5 mRNA in hippocampus and dentate gyrus. Scale bar (in $H$ ), $1000 \mu \mathrm{m}$. $C A$, CA1-CA3 areas of the hippocampal formation; $D G$, dentate Gyrus; $C X$, cortex; $T H$, thalamus; $H T$, hippothalamus; $A M$, amygdala; $P X$, piriform cortex. $G$, Ephrin-A5 and -A2 ligands are expressed in the hippocampus of both inbred strains of mice analyzed. Real-time quantitative (TaqMan) RT-PCR for mRNA of ligands ephrin-A5 and -A2 in the hippocampi of C57BL/6 (black bars) and DBA/2 (white bars). The data (mean \pm SEM) are based on the number of PCR amplification cycles required to reach a threshold level (cycles to threshold, $C T$ ) of cleavage of a fluorescent reporter probe (Gibson et al., 1996; Heid et al., 1996) and are normalized to GAPDH housekeeping gene transcript $(\Delta C T)$. Sample sizes $(n)$ indicate the number of mice analyzed. Note that larger values mean smaller original mRNA amount in the hippocampal tissue sample. Also note that amplification characteristics are unique to each gene; therefore, comparison from one gene to another is not valid. I, Western blot for phosphorylated EphA5. Each lane represents a hippocampal tissue sample from an individual mouse. Both DBA/2 $\left(a_{1}, a_{2}\right)$ and C57BL/6 $\left(b_{1}, b_{2}\right)$ strain of mice exhibit a prominent signal.

All experiments involving comparison of genotype or treatment groups were performed blind in a randomized manner.

In situ hybridization. For EphA5 in situ hybridization, 4-month-old DBA/2 and C57BL/6 mouse brains were fresh frozen with powdered dry ice. Sections were processed by a method described previously (Melton et al., 1984; Phillips et al., 1990). Probes were synthesized according to Melton et al. (1984) from a 407 DNA fragment that included nucleotides 3040-3446 (I. W. Caras and J. W. Winslow; patent WO9613518-A1; accession number P-T18893; 1996).

$R T-P C R$. Total RNA was isolated using the Qiagen (Hilden, Germany) RNeasy Mini Kit from $50 \mathrm{mg}$ mouse hippocampi freshly frozen in liquid nitrogen. RNA was aliquoted and stored at $-70^{\circ} \mathrm{C}$ until used. Oligonucleotide probes and primers were designed to recognize the genes using the Primer Express software [Applied Biosystems (Foster City, CA) and Perkin-Elmer (Emeryville, CA)]. Real-time quantitative RT-PCR (TaqMan) was performed and analyzed using the Promega (Madison, WI) Access RT-PCR System in the ABI Model 7700 Sequence Detection system (Gibson et al., 1996; Heid et al., 1996). Samples were run in duplicate with standard curves of Clontech (Cambridge, UK) mouse brain total RNA on every plate for all genes, and the linearity of amplification was confirmed (Gibson et al., 1996; Heid et al., 1996). The data shown are calculated from the standard curves, and each sample is normalized to GAPDH, a housekeeping gene, as described previously (Gibson et al., 1996; Heid et al., 1996).

Western blot. The methods are described in detail previously (Winslow et al., 1995; Gerlai et al., 1998b). Briefly, freshly harvested hippocampal tissue was homogenized, and EphA5 was immunoprecipitated using an anti-EphA5 antibody (Genentech, San Francisco, CA). Phosphorylation levels were tested using anti-phosphotyrosine kinase antibody (4G10; Upstate Biotechnology, Lake Placid, NY). In the first Western blot experiment to detect basal in vivo phosphorylation levels of EphA5, both hippocampi ( $\sim 60 \mathrm{mg}$ tissue) of each individual mouse was used for protein extraction for each lane of the gel electrophoresis. Because the signal strength was high, to detect further increases in phosphorylation 

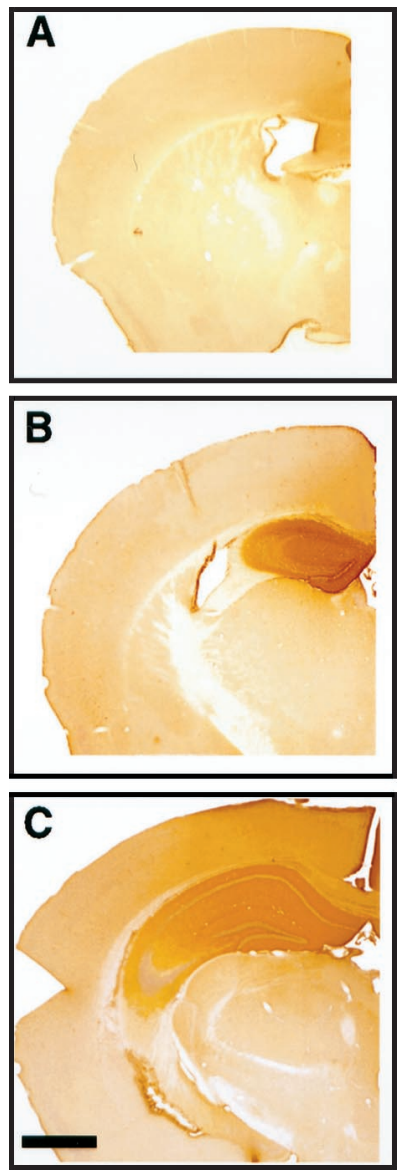

Figure 2. Immunohistochemical staining for the $\operatorname{IgG}$ domain of the immunoadhesin reveals pronounced hippocampal diffusion of the protein after $7 \mathrm{~d}$ intrahippocampal infusion from micro-osmotic pump. The right hemisphere with EphA5-IgG infusion in C57BL/6 mice is shown: $A$, anterior (bregma $-0.70 \mathrm{~mm}$ ); $B$, anterior (bregma $-1.35 \mathrm{~mm}$ ); $C$, posterior (bregma -2.50 ) to the cannula insertion site. Note the strong peroxidase (brown) staining observable in the hippocampus and the lack of staining in infrahippocampal areas. Note that staining of suprahippocampal cortical areas within $1 \mathrm{~mm}$ from the cannula insertion site was observed in some specimens. Scale bar, $1000 \mu \mathrm{m}$.

levels induced by ephrin A5-IgG, in the second Western blot experiment, a smaller amount $(\sim 15 \mathrm{mg})$ of hippocampal tissue was used and the blot was exposed to anti-phosphotyrosine kinase antibody for an $85 \%$ shorter time ( $2 \mathrm{hr}$ vs the previously applied $12 \mathrm{hr}$ incubation).

Stereotaxic surgery and infusion. Using a stereotaxic frame, mice received bilateral intrahippocampal implantation of cannulas as described in detail previously (Gerlai et al., 1998b) at position anteroposterior -1.5 , mediolateral +1.8 , as measured in millimeters from bregma, and dorsoventral $1.8 \mathrm{~mm}$ from flat skull surface. Cannulas were connected to a pair of ALZET 1007D micro-osmotic pumps (volume of $99 \mu \mathrm{l}$; pumping rate of $0.51 \mu \mathrm{l} / \mathrm{hr}$; delivery period of $\sim 8 \mathrm{~d}$; ALZET brain inf usion kit; Alza, Palo Alto, CA) placed subcutaneously on the back. For C57BL/6 mice, CD4-IgG (control) or EphA5-IgG (antagonist) immunoadhesins were infused $[4.8 \mathrm{mg} / \mathrm{ml}$ in artificial CSF (ACSF) containing (in $\mathrm{mm}$ ): $124 \mathrm{NaCl}, 3 \mathrm{KCl}, 2.4 \mathrm{CaCl} 2,2.4 \mathrm{MgSO}_{4} .7 \mathrm{H}_{2} \mathrm{O}, 1.25 \mathrm{KH} 2 \mathrm{PO} 4,26$ $\mathrm{NaHCO}$, and 10 D-glucose]. For DBA/2 mice, CD4-IgG or ephrinA5IgG was infused $(0.5 \mathrm{mg} / \mathrm{ml}$ in ACSF). In addition, ephrin A5-IgG (0.5 $\mathrm{mg} / \mathrm{ml}$ in ACSF) was also infused in C57BL/6. The length of infusion was chosen to be $8 \mathrm{~d}$ in both $\mathrm{C} 57 \mathrm{BL} / 6$ and DBA/2, which allowed the large and slowly diffusing immunoadhesins to fully inf use the dorsal part and to also reach the majority of the ventral part of the hippocampus (Gerlai et al., 1998b). To demonstrate behavioral effects, a large portion, especially the dorsal part, of the hippocampus must be influenced, as shown by lesion studies (Moser et al., 1995) or tetrodotoxin application (Lorenzini et al., 1996a,b). Thus, continuous and prolonged infusion

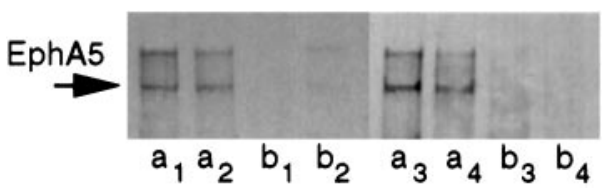

Figure 3. EphA5 receptor phosphorylation is induced by in vivo inf usion of the agonist ephrinA5-IgG in hippocampal tissue samples. After immunoprecipitation with anti-EphA5 antibody, phosphorylation levels were detected by anti-phosphotyrosine kinase antibody. Each lane represents hippocampal tissue from an individual mouse: $a$, ephrinA5-IgG inf usion; $b$, CD4-IgG infusion. Lanes 1-4 represent samples from C57BL/6; lanes 5-8 represent samples from DBA/2. The monomer (EphA5) protein is indicated.

decreased the hippocampal areas remaining uninfused and the possibility that such areas may render immunoadhesin effects unobservable.

Immunoadhesins. The design and production of immunoadhesins, as well as their advantages, including stability and detection, have been described and discussed in detail previously (Winslow et al., 1995; Chamow and Ashkenazi, 1996; Meima et al., 1997; Gerlai et al., 1998b). We used three different immunoadhesins in this study. EphA5-IgG contains the full ligand binding domain of the EphA5 receptors, but its signaling domain is replaced by the Fc portion of the IgG1 molecule, which includes the hinge region. This protein specifically binds to the ephrin-A ligands recognized by the EphA5 receptor, thus making them inaccessible to the endogenous receptor (antagonist). The second immunoadhesin is ephrinA5-IgG, which contains the receptor binding domain of the ephrin-A5 ligand linked to the $\mathrm{Fc}$ of IgG1. Because the hinge region of $\mathrm{Fc}$ confers flexibility and because the $\mathrm{Fc}$ is made up of two chains, this molecule has two conformationally correct and mobile receptor binding domains that mimic the behavior of membrane bound ephrin-A ligands in that, unlike a soluble ligand, they are capable of dimerizing, and thus activating, endogenous EphA receptors that ephrin-A5 recognizes. The third immunoadhesin used is CD4-IgG, a control molecule that is similar in molecular weight and composition to the active immunoadhesins but has no binding activity relevant in the CNS (Winslow et al., 1995; Chamow and Ashkenazi, 1996).

Immunohistochemistry. The methods followed standard protocols (Gerlai et al., 1998b). A biotinylated donkey anti-human IgG antibody (catalog \#709-65-149; Jackson ImmunoResearch, West Grove, PA) 1:200 in PBS was used to detect the IgG portion of the immunoadhesins. Brains were sectioned, and the sections were incubated in avidinbiotin-peroxidase complex (Elite ABC kit; Vector Laboratories, Burlingame, CA), rinsed, and developed using a standard diaminobenzidine reaction (Enhanced Metal; Pierce, Rockford, IL).

T-maze continuous spontaneous alternation task. The procedure followed the methods developed and described previously (Gerlai, 1998a). Note that, as conducted here, T-maze alternation test has been shown to be highly sensitive to hippocampal dysfunction. Mice were allowed to alternate between the left and right goal arms of the T-maze throughout a 15 trial session. Once they have entered a particular goal arm, a guillotine door was lowered to block entry to the opposite arm. The door was removed only after the mice returned to the start arm, thus allowing a new alternation trial to be started. Alternation rate was calculated as a ratio between the alternating choices and total number of choices $(50 \%$, random choice; $100 \%$, alternation at every trial; $0 \%$, no alternation). Time to complete 15 choices was also measured.

Fear conditioning. The methods have been described in detail previously (Gerlai, 1998b). Note that these methods were designed to maximize the context dependency and hippocampal sensitivity of the paradigm (Kim and Fanselow, 1992; Phillips and LeDoux, 1992; Abeliovich et al., 1993; Aiba et al., 1994; Paylor et al., 1994; Bach et al., 1995). Briefly, the paradigm had three phases: a training phase, a context-dependent test, and a cue-dependent test. For training, mice received three electric foot shocks (1 sec, $0.7 \mathrm{~mA}$ ), each preceded by an $80 \mathrm{~dB}, 2900 \mathrm{~Hz}$, 20 -sec-long tone cue in the Gemini avoidance apparatus (San Diego Instruments, San Diego, CA) as shown in Figures 5 and 7. Context and cue test apparatuses received olfactory cues different from those of training. The context test was performed in the training chamber, but no shock or tone was delivered. The cue test was performed in another chamber identical in size but different in visual, olfactory, and tactile cues from those of the training chamber. Tone signals identical to the one used in training but without a shock were given. Behavior was video- 


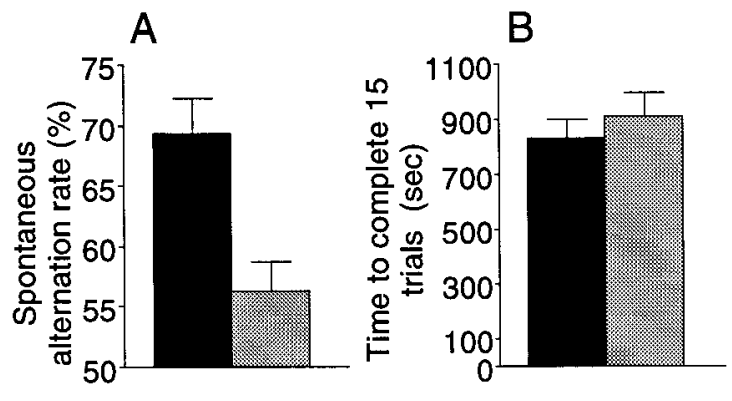

Figure 4. EphA5-IgG infusion impairs T-maze continuous alternation in C57BL/6 mice in a 15 trial alternation session. EphA5-IgG infusion, hatched bar, $n=23$; CD4-IgG infusion, black bar, $n=22$. One choice was allowed at each trial. Alternation rate is a ratio between the alternating choices and total number of choices. $A$, Significant difference was found in alternation rate $(t=3.528 ; \mathrm{df}=43 ; p<0.001)$. $B$, No significant difference was found between groups in time spent to complete the 15 choices $(t=0.915 ; \mathrm{df}=43 ; p>0.36)$. Error bars represent SEM.

recorded and later quantified using an event recording computer program (Observer; Noldus Information Technology, Wageningen, The Netherlands). Behavior elements, as indicated in Figures 5, 7, and 8, were analyzed. In a separate set of fear conditioning experiments, only one tone and shock stimulus pair was given during training, and only one tone cue was presented during cue testing. Other parameters and procedural details remained unchanged.

Electrophysiology. Transverse $300 \mu \mathrm{m}$ hippocampal slices were submerged in a recording chamber (Fine Science Tools Inc., Foster City, $\mathrm{CA})$, continuously perfused with $30^{\circ} \mathrm{C}$ oxygenated $\left(95 \% \mathrm{O} 2-5 \% \mathrm{CO}_{2}\right)$ ACSF for at least $1 \mathrm{hr}$ before recording. A bipolar glass electrode filled with ACSF stimulated Schaffer collaterals. Field EPSPs (fEPSPs) elicited by single-pulse stimulation at $0.2 \mathrm{~Hz}$ were recorded in CA1 stratum radiatum by a glass electrode filled with $\mathrm{ACSF}$. Input/output $(\mathrm{I} / \mathrm{O})$ characteristics and ratio of the fEPSP slope to the presynaptic fiber volley (PSFV) amplitude were used to estimate basal synaptic transmission. I/O characteristics, recorded by applying gradually increased (in 20 steps increments) stimulus intensity to evoke fEPSP from minimum to maximum slope, were estimated by Michaelis-Menten sigmoid curve fit. $\mathrm{Km}_{50}$ was taken as a $50 \%$ point between the threshold and maximal response (A/DVANCE software; McKellar Designs). Baseline was recorded for 1 hr with the stimulus intensity set to evoke a fEPSP that was $30-50 \%$ of the maximal slope. Paired-pulse facilitation (PPF) was evoked by applying paired pulses of the same intensity as for baseline recording with interpulse intervals of 50,100, 150, 200, and $250 \mathrm{msec}$. LTP was elicited by applying four trains of $100 \mathrm{~Hz}$ tetanus (1 sec duration, $20 \mathrm{sec}$ apart), with the same stimulus intensity as for the baseline and PPF. In our attempt to test the potential improving effects of ephrinA5-IgG on synaptic plasticity in slices from C57BL/6 mice, we used another protocol of tetanization that is subthreshold for LTP induction. In this set of experiments (for results, see Fig. 12), one train of $100 \mathrm{~Hz}$ tetanus was applied for $1 \mathrm{sec}$ with stimulus intensity set to evoke a fEPSP $10-15 \%$ of maximal slope. Recordings in all experiments were made with an Axoprobe-1A amplifier (Axon Instruments, Foster City, CA) interfaced with a Power Macintosh 7100/66 computer (Apple Computers, Cupertino, CA). Data were acquired, digitized, and analyzed using A/DVANCE software (McKellar Designs).

Statistical analysis. Data were analyzed by $t$ test, repeated-measures ANOVA, and post hoc Tukey's honestly significant difference (HSD) test. Variance homogeneity was tested by Bartlett's test. Only relevant main effects are presented; detailed data analysis results are available on request.

\section{RESULTS}

\section{Expression pattern of EphA5 and its ligands in the adult mouse brain}

Using in situ hybridization (Melton et al., 1984; Phillips et al., 1990), we found strong expression of EphA5 mRNA in pyramidal neurons of all hippocampal CA fields and in dentate gyrus granule cells in the hippocampal formation in adult mice from inbred strains C57BL/6 (Fig. $1 B, C$ ) and DBA/2 (Fig. $1 E, F$ ). In addition, expression was detected in the cortex (e.g., piriform cortex), amygdala, thalamus, and hypothalamus (Fig. 1). In situ hybridization could not reveal a clear signal, but a more sensitive quantitative RT-PCR (Gibson et al., 1996; Heid et al., 1996) demonstrated the presence of ephrin-A5 and -A2 (the preferred ligands of EphA5) (Frisén et al., 1998) mRNA in the hippocampus of both mouse strains (Fig. $1 G$ ), and the expression levels were not different between strains (ephrin-A5, $t=0.447$; df $=10 ; p>0.60$; ephrin-A2, $t=0.008$; df $=10 ; p>0.99)$. Furthermore, using Western blot analysis (for review, see Winslow et al., 1995; Gerlai et al., 1998b), we revealed that EphA5 protein is present in the mature hippocampus in both strains in a phosphorylated, activated form (Fig. 1I), implying that EphA5 is involved in some aspect of neural function in the adult mouse CNS.

\section{Infusion of immunoadhesins into the hippocampus}

To confirm that the antagonist immunoadhesin EphA5-IgG and the agonist immunoadhesin ephrinA5-IgG binds to their relevant targets under conditions similar to those of the in vivo application we were planning $\left(37^{\circ} \mathrm{C}\right.$; ALZET micro-osmotic pump), ELISA essay was performed. The immunoadhesin solution was injected into a micro-osmotic pump, the pump was placed in a thermostat at $37^{\circ} \mathrm{C}$, and the solution was sampled over a $10 \mathrm{~d}$ period. The results (data not presented) showed that both immunoadhesins retained a significant and specific binding capacity.

To study EphA function, we infused the antagonist or agonist immunoadhesin bilaterally into the hippocampus using microosmotic pumps (Gerlai et al., 1998b). The result of infusion, analyzed by immunostaining, showed homogeneous immunoadhesin distribution within the hippocampus (Fig. $2 A, B$ ). Cortical areas within $1 \mathrm{~mm}$ surrounding the cannula insertion site were also stained in some samples, but other cortical areas or infrahippocampal structures remained uninf used. As shown previously by magnetic resonance imaging and immunocytochemistry (Gerlai et al., 1998b), immunoadhesin infusion did not lead to detectable physical damage, edema, or inflammation in the brain. Furthermore, no gross morphological changes were observed at the light microscope level using immunostaining for NMDA-R1, GluR1, PKC, GABA, synaptobrevin, and synaptotagmin, or Nissl stain (data not shown). Last, all mice appeared well groomed and healthy, exhibited no abnormal behaviors in their home cage, and achieved normal life span when allowed to age (data not shown).

Consistent with its antagonist action, EphA5-IgG was shown previously to impair phosphorylation of the EphA5 receptor (Winslow et al., 1995; Meima et al., 1997). The evidence for the contrary, i.e., for an agonist action, was lacking. Using Western blot analysis, here we show that EphA5 phosphorylation can be elevated above basal levels in vivo by ephrinA5-IgG infusion in the hippocampus (Fig. 3). The correct molecular weight for the monomer EphA5 protein is shown, and the signal above it represents the dimerized form of the protein.

To determine whether EphA receptors mediate neural function, we focussed our attention to the hippocampus because of the expression pattern of EphA5 and also because of the availability of behavioral paradigms and electrophysiological methods sensitive to detect dysfunction of this structure. We put considerable emphasis on behavioral analysis because it offers a sensitive way to detect neural functional changes (Gerlai, 1996c; Gerlai and Clayton, 1999). 


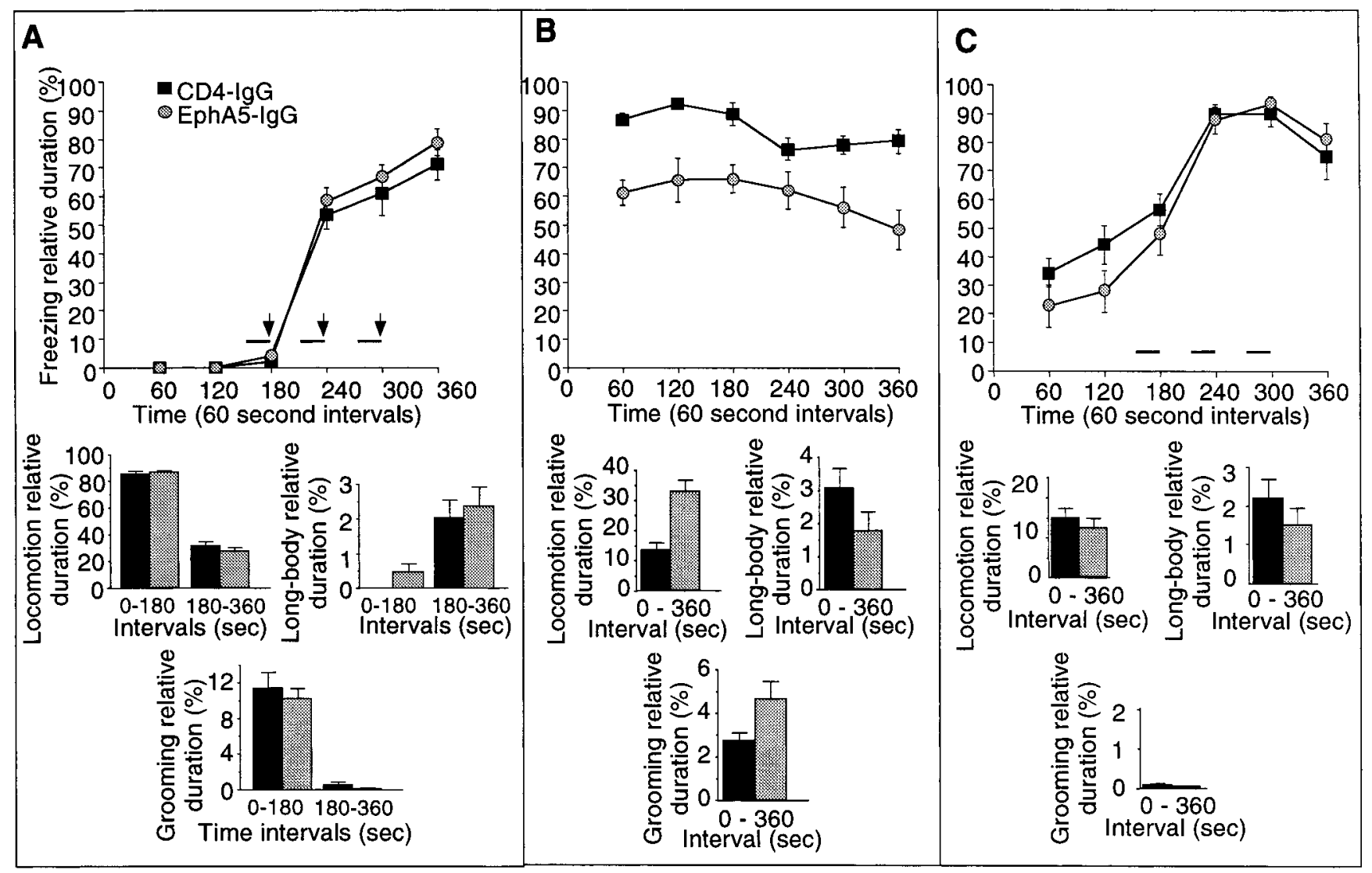

Figure 5. EphA5-IgG inf usion impairs learning performance in a context-specific manner in fear conditioning in C57BL/6 mice. In the CDFC paradigm, mice associate two substantially different types of cues with a negative reinforcer, an electric foot shock. The shock is paired with a simple associative cue, a tone, in a shock chamber characterized by multiple contextual cues. A, During training, mice were given three 20 sec tone signals (solid horizontal bars) that coterminated with 1-sec-long electric shocks $(0.5 \mathrm{~mA}$; arrows $)$. Both CD4-IgG- $(n=22)$ or EphA5-IgG-infused mice $(n=23)$ responded to training with increased freezing, a natural response to painful stimuli, and no significant differences were seen between groups. Relative duration (percentage; time per $60 \mathrm{sec}$ ) of freezing behavior is shown for $60 \mathrm{sec}$ intervals. In addition to freezing, three other behavioral elements (bar graphs under line diagrams) are also shown. Note that fear correlates negatively with locomotion and grooming and positively with long-body. No significant differences were detected between the mice in any of the behavioral measures either before (interval $0-180$ sec) or after (interval 180-360 sec) shock. $B$, A randomly assigned subset of trained mice $(n=16$ for CD4-IgG-inf used; $n=17$ for EphA5-IgG-inf used) was tested in the shock chamber for response to contextual stimuli. No tone cues or shocks were given. The freezing behavior (line diagram) of EphA5-IgG-inf used mice was significantly impaired compared with that of the CD4-IgG-infused animals $\left(F_{(1,31)}=24.926 ; p<0.0001\right)$. In addition to freezing, relative duration of three other behavioral elements (bar graphs) is also shown for the entire session. EphA5-IgG-inf used mice were found to exhibit an increased amount of locomotion $(t=4.315 ; \mathrm{df}=31 ; p<0.0001)$ and grooming $(t=2.133 ; \mathrm{df}=31 ; p<0.05)$ and exhibited decreased long-body posture $(t=2.100 ; \mathrm{df}=31 ; p<0.05)$, all suggesting decreased level of fear. $C$, A randomly assigned subset of trained mice $(n=12$ for CD4-IgG; $n=13$ for EphA5-IgG) was tested in the cued test. The cued test was conducted in a chamber that lacked the olfactory, visual, and tactile cues (the contextual stimuli) of the shock chamber. Mice received three tone signals alone (solid horizontal bars) but no shock. Both groups of mice responded to the tone cue with a robust increase in freezing (line diagram), and no significant differences were found between the two groups of mice on freezing $\left(F_{(1,23)}=2.068 ; p>0.15\right)$ or any of the other behavioral measures (bar graphs) analyzed $(t<0.99 ; \mathrm{df}=23 ; p>0.30)$. Data obtained in fear conditioning are shown as mean $\pm \mathrm{SEM}$.

\section{Behavioral changes elicited by immunoadhesin infusion}

We use the availability of two inbred strains of mice, C57BL/6 and DBA/2, that exhibit striking differences in hippocampal function at the behavioral level (Paylor et al., 1994; Gerlai, 1998a,b). First, we infused EphA5-IgG or a control immunoadhesin, CD4$\mathrm{IgG}$, bilaterally into the hippocampus of adult C57BL/6 mice for $8 \mathrm{~d}$ and then tested behavioral performance in the T-maze continuous spontaneous alternation task (T-CAT), a newly developed paradigm sensitive to detect hippocampal dysfunction and abnormalities that affect spatial learning and working memory (Gerlai, 1998a). C57BL/6 mice infused with the control CD4-IgG immunoadhesin exhibited an excellent alternation rate (Fig. 4A), a performance typical for intact mice of this strain (Douglas, 1990; Gerlai, 1998a). In contrast, mice inf used with EphA5-IgG exhibited a significantly impaired alternation rate (Fig. $4 A$ ). The im- pairment is unlikely to be caused by altered motor performance or motivation levels, because both groups of mice finished the task within the same amount of time (Fig. 4B). Furthermore, the impairment is also unlikely to be caused by altered sensory capabilities because the task can be solved using multiple modalities of cues whose processing is distributed in several brain areas left unaffected by the immunoadhesin infusion.

The deficit in EphA5-IgG-infused mice was further characterized using context-dependent fear conditioning (CDFC), a configural learning task also found sensitive to hippocampal dysfunction (Kim and Fanselow, 1992; Phillips and LeDoux, 1992; Abeliovich et al., 1993; Aiba et al., 1994; Bach et al., 1995; Gerlai, 1998b). The reason to conduct this additional behavioral test was that CDFC and T-CAT are associated with different motor (Tmaze: activity; CDFC: passivity), perceptual (T-maze: extramaze visual cues; CDFC: intramaze visual, olfactory, tactile, and 
auditory cues), and motivational (T-maze: spontaneous curiosity; CDFC: negatively reinforced fear) requirements, yet both tests are sensitive to hippocampal dysfunction. Thus, comparison of T-maze and CDFC performance may allow one to dissociate simple performance deficits or improvements from alterations in hippocampal (cognitive) function. In the CDFC paradigm, hippocampal damage results in the loss of freezing (a natural response to pain or fear) to contextual cues, although sparing response to a simple associative cue (Kim and Fanselow, 1992; Phillips and LeDoux, 1992) (see also Gerlai, 1998b). After training, control (CD4-IgG-infused) C57BL/6 mice exhibited a substantial freezing response to both a simple associative cue (cued task) and complex contextual cues (context-dependent task) (Fig. $5 B, C)$. Compared with controls, mice treated with EphA5-IgG showed a significant deficit in the context-dependent task but not in the cued task (Fig. 5B,C). The performance deficit of the EphA5-IgG-treated mice is unlikely to be caused by sensory, motor, or motivational disturbances, because no differences were seen between responses of EphA5-IgG and CD4-IgG mice during either the training session or in the cued task (Fig. $5 A, C$ ). Furthermore, because the deficit was specific to the context task, it is unlikely to be attributable to a generalized learning defect or health-related problems. To further ascertain that changes in the freezing response was not simply caused by altered motor performance, i.e., ability to remain motionless, other behavioral elements associated with fear (Blanchard and Blanchard, 1969; Gerlai et al., 1993), including locomotion and grooming (negative correlation with fear), and long-body posture (positive correlation with fear) (Fig. 5, bottom panels) were also measured. Analysis of these elements confirmed the context-specific nature of the learning performance deficit.

It is unlikely that a context-specific learning deficit induced by the EphA antagonist may result from nonspecific disruption of brain function unrelated to learning. Nevertheless, to rule out this possibility, one may need to show improved learning performance in response to EphA activation. Thus, ephrinA5-IgG, the agonist immunoadhesin (Winslow et al., 1995; Meima et al., 1997), was bilaterally infused into the hippocampus of DBA/2 mice, a strain that displays deficits in hippocampal learning tasks and other measures of hippocampal function (Crusio et al., 1990; Matsuyama et al., 1997; Gerlai, 1998b). DBA/2 mice infused with ephrinA5-IgG exhibited an improvement in performance in both T-CAT and CDFC paradigms (Figs. 6, 7). Whereas control DBA/2 mice infused with CD4-IgG did not alternate above chance level on the T-CAT, a performance typical of this strain (Gerlai, 1998a), the alternation rate of mice treated with ephrin A5-IgG was increased significantly above chance and the rate of the control mice (Fig. $6 A$ ), but the time to complete the task remained unchanged (Fig. 6B). In the CDFC paradigm, ephrinA5-IgG infusion elicited a selective improvement on the context-dependent task (Fig. $7 B$ ), a performance enhancement most probably attributable to cognitive rather than sensory, motor, or motivational effects (Fig. 7A,C). Again, the changes were observable not only in freezing but in the other behavioral measures of fear (Fig. 7, bottom panels).

To investigate whether the improving effects of intrahippocampal ephrinA5-IgG infusion are generalizable to other mouse strains, we infused C57BL/6 mice with this immunoadhesin or the control CD4-IgG. Normal C57BL/6, or CD4-IgG-infused C57BL/6, mice exhibit good contextual and cue-dependent learning performance in fear conditioning (Gerlai, 1998b; Gerlai et al., 1998b) (Fig. 5). The high freezing values may represent a ceiling
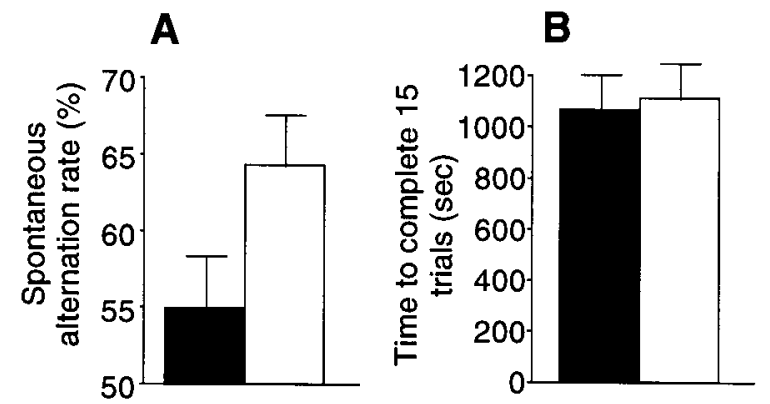

Figure 6. Infusion of ephrinA5-IgG in DBA/2 mice improves spontaneous alternation rate in the T-maze (T-CAT paradigm). $A$, EphrinA5-IgGtreated mice (white bar; $n=19$ ) exhibited higher levels of alternation compared with CD4-IgG-infused mice (black bar; $n=17 ; t=2.85$; $\mathrm{df}=$ $34 ; p<0.01)$. $B$, Time spent to complete 15 alternation trials did not differ between treatment groups $(t=0.365 ; \mathrm{df}=34 ; p>0.710)$, suggesting that the improved alternation performance is not caused by motoric or motivational influences. Error bars represent SEM. Methods as in Figure 4 (also see Materials and Methods).

problem in a learning paradigm in which further improvements are expected. Indeed, ephrinA5-IgG-infused C57BL/6 mice showed excellent performance in both the context and the cue tests (reaching $80-90 \%$ freezing), but they were statistically indistinguishable from control mice inf used with CD4-IgG, which also froze at that level (repeated-measures ANOVA; training immunoadhesin effect, $F_{(1,15)}=2.042 ; p>0.170$; time $\times$ immunoadhesin interaction, $F_{(5,75)}=1.874 ; p>0.10$; context test immunoadhesin effect, $F_{(1,15)}=0.017 ; p>0.890$; immunoadhe$\sin \times$ time interaction, $F_{(5,75)}=1.088 ; p>0.370$; cue test immunoadhesin effect, $F_{(1,15)}=2.458 ; p>0.135$; immunoadhe$\sin \times$ time interaction, $\left.F_{(5,75)}=1.905 ; p>0.10\right)$. Although these results suggest that ephrinA5-IgG has no deleterious effects on contextual or cued learning performance, they do not allow us to ascertain whether this immunoadhesin can lead to improvements in $\mathrm{C} 57 \mathrm{BL} / 6$ mice. To achieve submaximal performance in C57BL/6 and avoid this ceiling problem, we modified the fear conditioning paradigm and presented only one tone-shock stimulus pairing instead of three. This stimulation has been shown to lead to a lower freezing performance $(30-40 \%)$ level in the context test (Silva et al., 1996), presumably indicating the formation of a less robust memory.

The results of the one stimulus pair CDFC test convincingly demonstrated that ephrinA5-IgG improved performance in C57BL/6 mice in a context-dependent manner (Fig. 8). Figure $8 A$ shows that all mice responded to a single tone-shock presentation with increased freezing, although the increase was less robust compared with when three such stimulus pairs were administered. Freezing response to context $1 \mathrm{~d}$ after training was at $30-40 \%$ level in the control CD4-IgG-infused mice (Fig. $8 B$ ), a performance similar to that reported previously in normal mice in this training paradigm (Silva et al., 1996). However, freezing performance in the context task was significantly increased to $60-70 \%$ (Fig. 8B) in mice inf used with ephrinA5-IgG. Cued task performance was unaltered, and both groups of mice responded to the presentation of a single tone cue with a significant and equivalent increase of freezing (Fig. $8 C$ ). The context-specific performance enhancement was confirmed by the results of the other behavioral elements (Fig. 8, bottom panels), including locomotion, long-body, and grooming, all suggesting an elevated fear response to context in ephrinA5-IgG-infused mice but unaltered responses in training and cue test compared with CD4-IgG-infused animals. These 


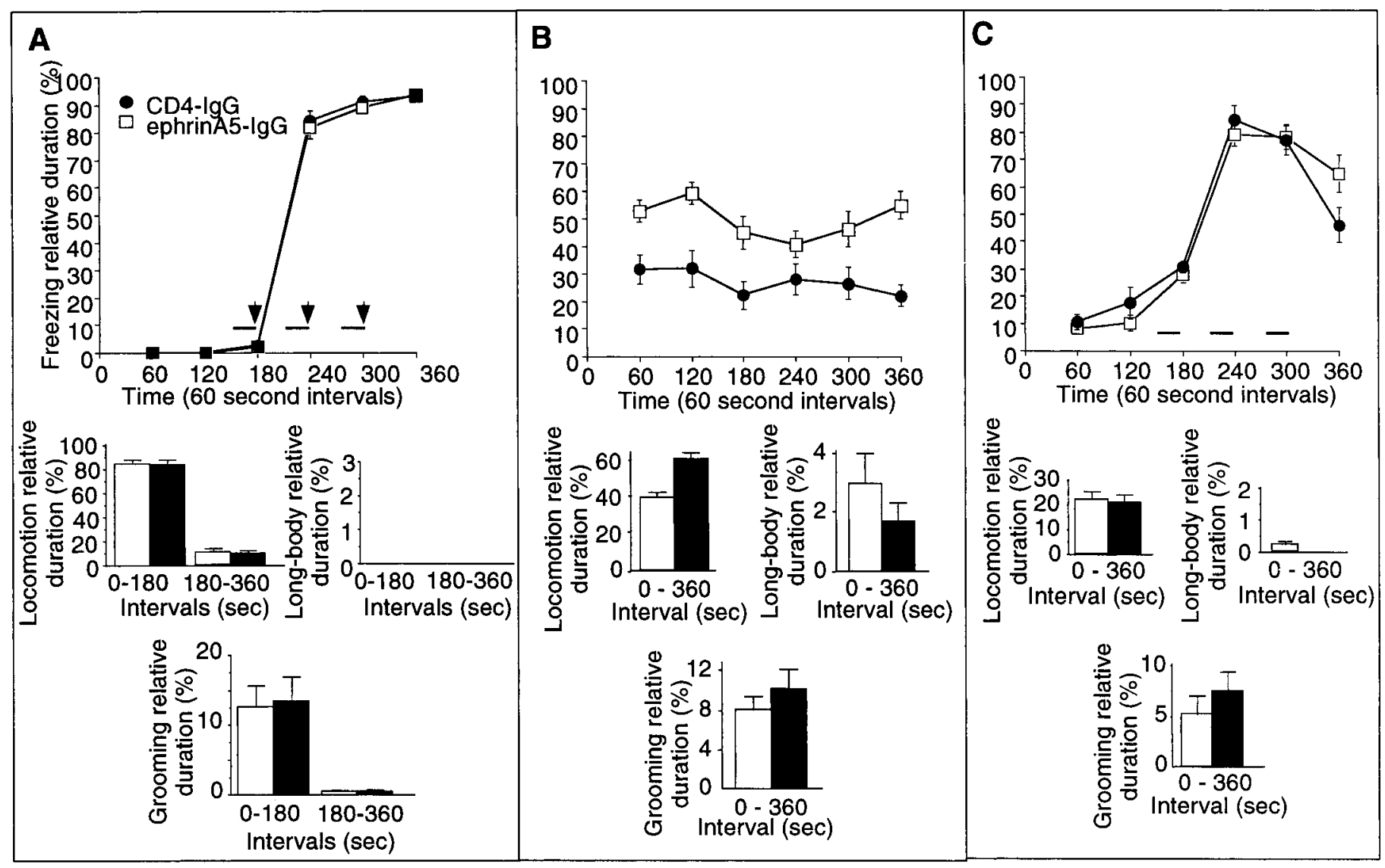

Figure 7. EphrinA5-IgG inf usion significantly improves learning performance in a context-specific manner in fear conditioning in DBA/2 strain of mice. Methods are described in detail previously (Gerlai, 1998b). $A$, In the training session, no significant differences were found between ephrinA5-IgGinfused (white squares; $n=19$ for training and tests) and CD4-IgG-infused (black circles; $n=17$ for training and tests) mice in any of the behaviors (freezing: line diagram; other behavioral elements: bar graphs) measured, suggesting normal perceptual and motor performance. $B$, Response to contextual stimuli is shown. The freezing performance (line diagram) of ephrinA5-IgG-infused mice was significantly improved compared with the CD4-IgG-inf used animals throughout the test session $\left(F_{(1,34)}=33.434 ; p<0.0001\right)$. In addition to freezing, increased level of fear in EphrinA5-IgGinf used mice is also indicated by changes in other behavioral elements (bar graphs). $C$, In the cued test, mice were placed in a chamber in which contextual stimuli were different from those of the shock chamber as explained in Figure 5C. The mice received three tone signals alone (solid horizontal bars) but no shock. All mice responded to the tone cue with a robust increase in freezing (line diagram), and no significant difference was found between the two groups of mice in freezing $\left(F_{(1,34)}=0.004 ; p>0.95\right)$ or in any of the other behavioral measures (bar graphs) analyzed.

results confirm that the performance enhancement is not caused by changes in motor or perceptual abilities but by improved cognitive function and that this improvement is not unique to DBA/2 but can also be observed in C57BL/6 mice.

\section{Gene expression changes induced by immunoadhesin infusion}

Given the presynaptic and postsynaptic localization of EphA receptors (W.-Q. Gao et al., 1998), their role in synapse formation during development, and their suggested involvement in cytoskeletal processes (Meima et al., 1997; Torres et al., 1998), to investigate potential mechanisms underlying the observed behavioral changes, we tested gene expression of neuronal, synaptic, and cytoskeletal markers. RT-PCR for synaptophysine and NMDA-R1 performed on hippocampal tissue samples from mice infused in vivo for $8 \mathrm{~d}$ with the immunoadhesins showed no differences in expression levels (data not shown). However, mRNA expression of the tubulin gene (M- $\alpha 1)$, whose product is a cytosolic microtubular protein involved in dendritic and axonal cytoskeletal processes, showed significant immunoadhesininduced changes. Tubulin mRNA expression tested by RT-PCR showed that EphA5-IgG increases and ephrinA5-IgG decreases transcription (Fig. 9A) from this gene, a finding consistent with the growth-arresting repulsive effects of the ephrin-A5 ligand during CNS development. Furthermore, another cytoskeletal protein, the microtubule-associated protein MAP2 involved in neuronal activity-dependent dendritic structural changes (Quinlan and Halpain, 1996) also showed a similar trend. Although nonsignificant, MAP2 mRNA expression appeared higher in hippocampal tissue infused in vivo for $8 \mathrm{~d}$ with EphA5-IgG and lower in hippocampal samples infused with ephrinA5-IgG compared with CD4-IgG control (Fig. 9B). Note that mRNA expression is shown as the number of PCR cycles required to reach a threshold level of cleavage of a fluorescent reporter probe (Gibson et al., 1996; Heid et al., 1996), and this measure is inversely related to the original amount of mRNA present in the sample. Because EphA receptors are involved in neuronal cytostructural mechanisms during the embryonic development of the brain (Friedman and O'Leary, 1996; Gao et al., 1996; Zhang et al., 1996; Meima et al., 1997; Orioli and Klein, 1997; Zhou, 1997; Flanagan and Vanderhaegen, 1998; Frisén et al., 1998; P. P. Gao et al., 1998), the above results suggest that these receptors retain this function in the adult brain. 


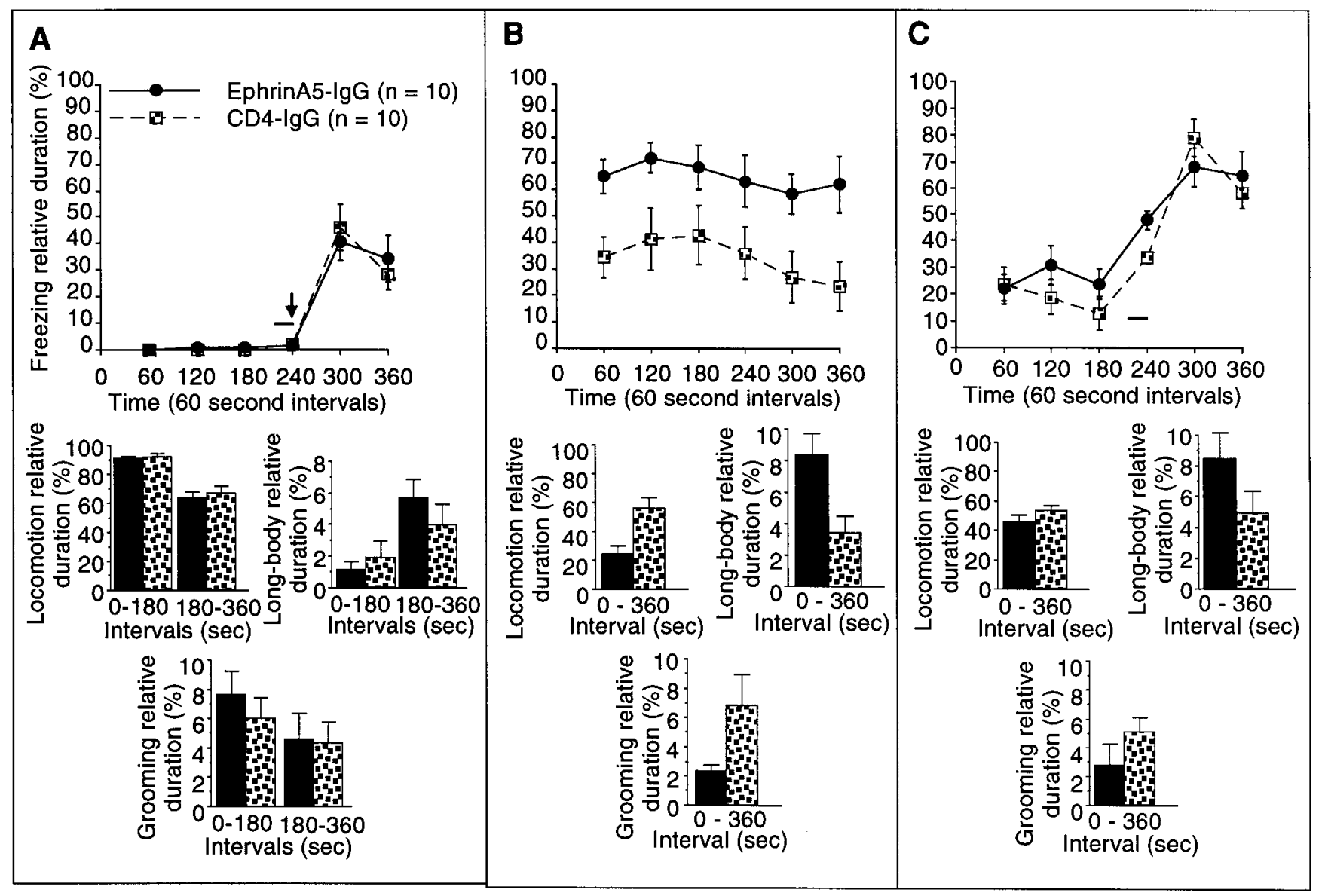

Figure 8. EphrinA5-IgG infusion significantly improves learning performance in a context-specific manner in fear conditioning in C57BL/6 mice. Methods are described in detail previously (Silva et al., 1996; Gerlai, 1998b). $A$, In the training session, no significant differences were found between ephrinA5-IgG-inf used (black circles; $n=10$ for training and tests) and CD4-IgG-inf used (checkered squares; $n=10$ for training and tests) mice in any of the behaviors measured (freezing: line diagram; other behavioral measures: bar graphs), suggesting normal perceptual and motor performance. Note that, to achieve a submaximal freezing response, only one tone (solid line) and shock (arrow) stimulus pairing was administered. B, Response to contextual stimuli is shown. The freezing performance (line diagram) of ephrinA5-IgG-infused mice was significantly improved compared with the CD4-IgG-inf used animals throughout the test session $\left(F_{(1,18)}=7.86 ; p=0.01\right)$. In addition to freezing, increased level of fear in EphrinA5-IgG-inf used mice is also indicated by decreased locomotion $(t=3.236 ; \mathrm{df}=1 ; p<0.01)$, increased long-body posture $(t=2.83 ; \mathrm{df}=1 ; p=0.01)$, and decreased grooming $(t=2.024 ; \mathrm{df}=1 ; p=0.058)$ (bar graphs). $C$, In the cued test, mice were placed in a chamber in which contextual stimuli were different from those of the shock chamber as explained in Figure 5C. The mice received one tone signal alone (solid horizontal bar) but no shock. All mice responded to the tone cue with a robust increase in freezing (line diagram), and no significant difference was found between the two groups of mice in freezing $\left(F_{(1,18)}=0.714 ; p>0.40\right)$ or the other behavioral measures (bar graphs) analyzed except long-body, which remained slightly increased in ephrinA5IgG-infused mice.

\section{Immunoadhesin infusion alters synaptic plasticity}

Hippocampal LTP is a cellular mechanism proposed to underlie spatial and configural learning in rodents (Bliss and Collingridge, 1993). Therefore, we also studied whether potential alterations in LTP may accompany the observed behavioral changes. Hippocampal slices prepared from mice infused in vivo with EphA5IgG or ephrinA5-IgG for $8 \mathrm{~d}$ were analyzed. In slices from C57BL/6 mice infused with EphA5-IgG, the induction of LTP appeared normal, but the potentiated response decayed significantly faster compared with slices obtained from CD4-IgG control C57BL/6 mice (Fig. 10A). The decay was not caused by a putative inability of the slice to exhibit larger fEPSPs because a second tetanus applied at the end of the recording session was able to reinduce a high level of LTP (data not shown). Other synaptic parameters, such as paired-pulse facilitation, and basal synaptic transmission (Fig. 10B,C) remained unaltered by EphA5-IgG infusion.

The enhancement of cognitive function by ephrinA5-IgG in- fusion seen in DBA/2 mice was also accompanied by changes in hippocampal synaptic function. Slices from DBA/2 mice inf used with ephrinA5-IgG exhibited a significant augmentation of LTP, beginning at induction and persisting up to $4.5 \mathrm{hr}$ (Fig. 11A). EphrinA5-IgG treatment also increased PPF (Fig. 11B), suggesting the involvement of a presynaptic mechanism, whereas basal synaptic transmission was unchanged (Fig. 11C). Furthermore, although LTP induced by the standard four train stimulation protocol (see Materials and Methods) appeared almost identical in C57BL/6 mice infused with CD4-IgG or ephrinA5-IgG (immunoadhesin effect, $F_{(1,8)}=0.043 ; p>0.80$; immunoadhesin $\times$ time interaction, $\left.F_{(30,240)}=0.917 ; p>0.50\right)$, probably attributable to a robust LTP response leading to a ceiling effect, LTP induced by a single train and lower amplitude of electric stimulation showed a trend in $\mathrm{C} 57 \mathrm{BL} / 6$ similar to the observations in DBA/2, suggesting a facilitatory effect of ephrinA5-IgG (Fig. 12) in both strains. It is notable, however, that although the electrophysiological and behavioral findings are generally in agreement 


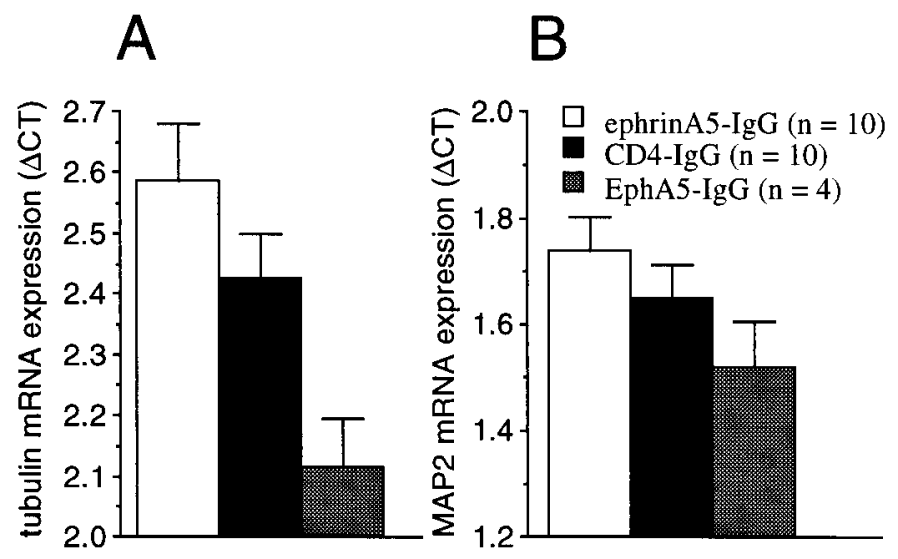

Figure 9. Transcriptional changes induced by immunoadhesins in two cytoskeletal proteins, tubulin $(A)$ and MAP2 $(B)$. No strain differences were found. The data (mean \pm SEM) are pooled for the strains and are based on the number of PCR amplification cycles required to reach a threshold cleavage level of fluorescent reporter probe ${ }^{18,19}$. Results normalized to GAPDH housekeeping gene transcript are shown $(\Delta C T)$. Sample sizes $(n)$ are also indicated. Note that larger values represent smaller original mRNA amount in the hippocampal tissue sample analyzed. Note that expression of tubulin mRNA is increased by EphA5-IgG and decreased by ephrinA5-IgG infusion (ANOVA; $F_{(2,21)}=5.02 ; p<$ $0.02)$. Expression changes in MAP2 show a similar but nonsignificant trend $\left(\mathrm{ANOVA} ; F_{(2,21)}=1.75 ; p>0.19\right)$.

with each other, the correlation is not perfect. For example, ephrinA5-IgG infusion was able to elicit a significant behavioral improvement in both $\mathrm{DBA} / 2$ and $\mathrm{C} 57 \mathrm{BL} / 6$. This may be attributable to the genetic background of the two mouse strains differentially affecting behavioral and electrophysiological phenotypes and/or to different sensitivity and resolution of the electrophysiological and behavioral methods applied.

\section{DISCUSSION}

Our in situ hybridization findings demonstrating strong EphA5 expression in neurons of the adult mouse hippocampus, RT-PCR results showing hippocampal expression of two relevant ligands of this receptor, ephrin-A2 and -A5, and our Western blot analysis revealing the presence of EphA5 receptor in a phosphorylated active form in hippocampal tissue from adult mice, strongly suggest that EphA receptor function is not restricted to the developing nervous system. Confirming this suggestion, intrahippocampal infusion of an EphA antagonist led to significant impairment in behavioral function in adult mice, whereas infusion of an agonist resulted in improved behavioral performance. Furthermore, infusion of the antagonist led to increased expression of a cytostructural protein, tubulin, and also impaired some electrophysiological measures of hippocampal synaptic plasticity, whereas infusion of the agonist resulted in decreased tubulin expression and improved electrophysiological performance.

These results were achieved using protein targeting, a novel strategy in behavioral neuroscience that may have some advantages over more conventional methods (Gerlai et al., 1998b). The applied genetically engineered immunoadhesins recognize the ligand, or the receptor, on the basis of high-affinity natural ligand receptor binding interaction (Winslow et al., 1995; Chamow and Ashkenazi, 1996); thus, they obviate the lack of EphA-selective pharmacological agents. Furthermore, as a result of the unaltered binding sites, these immunoadhesins are capable of binding all relevant proteins that the endogenous EphA5 or ephrin-A5 molecules would bind. Because EphA receptors are promiscuous and
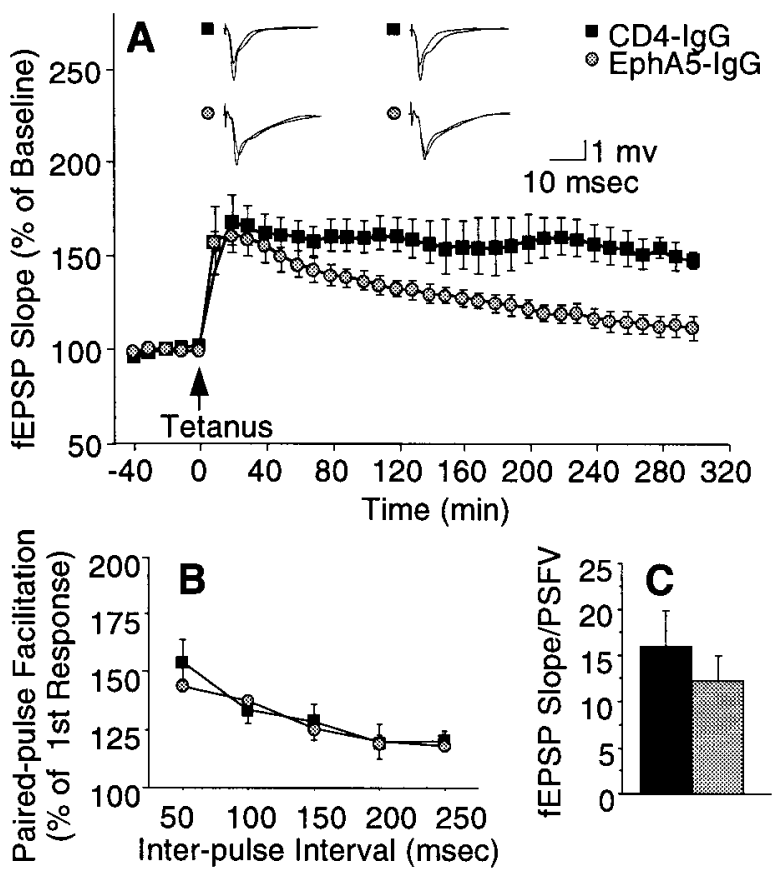

Figure 10. EphA5-IgG impairs LTP maintenance in hippocampal slices prepared from C57BL/6 mice. $A$, Field EPSP is expressed as percentage of baseline. Twenty sequential responses were averaged and plotted as one point. ANOVA revealed a significant immunoadhesin effect $\left(F_{(1,8)}=\right.$ $8.09 ; p=0.02)$ and a significant immunoadhesin $\times$ time interaction $\left(F_{(29,232)}=4.98 ; p<0.0001\right)$. Tukey's HSD test showed that the groups became significantly different $(p<0.05) 90 \mathrm{~min}$ after tetanization. Representative traces before and after tetanization at corresponding time points, as indicated, are also shown. $B$, No immunoadhesin effect was observed on paired pulse facilitation $\left(F_{(1,11)}=0.164 ; p>0.690\right)$, which was assessed by applying paired pulses of equivalent intensity at interpulse intervals as indicated. Facilitation ratios are calculated by expressing the slope of the second fEPSP as a percentage of the slope of the first fEPSP. $C$, Basal synaptic transmission, estimated by ratio of the fEPSP slope to the PSFV amplitude, was not altered by EphA5-IgG-infused (hatched bar) compared with CD4-IgG-infused (black bar) mice $(t=$ $1.119 ; \mathrm{df}=14 ; p>0.28)$. Estimation of basal synaptic transmission by $\mathrm{I} / \mathrm{O}$ characteristics using Michaelis-Menten sigmoid curve fit revealed no significant differences (CD4-IgG, mean of $1.30 \pm 0.368$; EphA5-IgG, mean of $1.54 \pm 0.219 ; p>0.80)$.

may respond to several ephrin-A ligands, and conversely a ligand may activate several receptors (Orioli and Klein, 1997), these immunoadhesins allowed us to manipulate all functionally relevant ligands or receptors without the confounding effects of compensation by closely related ligands or receptors as occur in gene targeting (Gerlai 1996a,b; Frisén et al., 1998). Furthermore, stereotaxic delivery of the immunoadhesins into the hippocampus eliminated the possibility of inducing developmental defects during ontogenesis and also reduced the confounding effects of nonspecific changes in tissues not associated with hippocampal function (Gerlai, 1996a).

Our results indicate that inhibition and augmentation of EphA function by intrahippocampal infusion of the immunoadhesins in adult mice impairs and facilitates, respectively, behavioral responses in two tasks, T-CAT and CDFC. These tasks depend on the hippocampus (Gerlai, 1998a,b) but have different motivational, perceptual, and motor requirements. Therefore, the consistent behavioral changes we observed imply an underlying mechanism associated with hippocampal function and not with idiosyncratic characteristics unique to one or the other task, a 

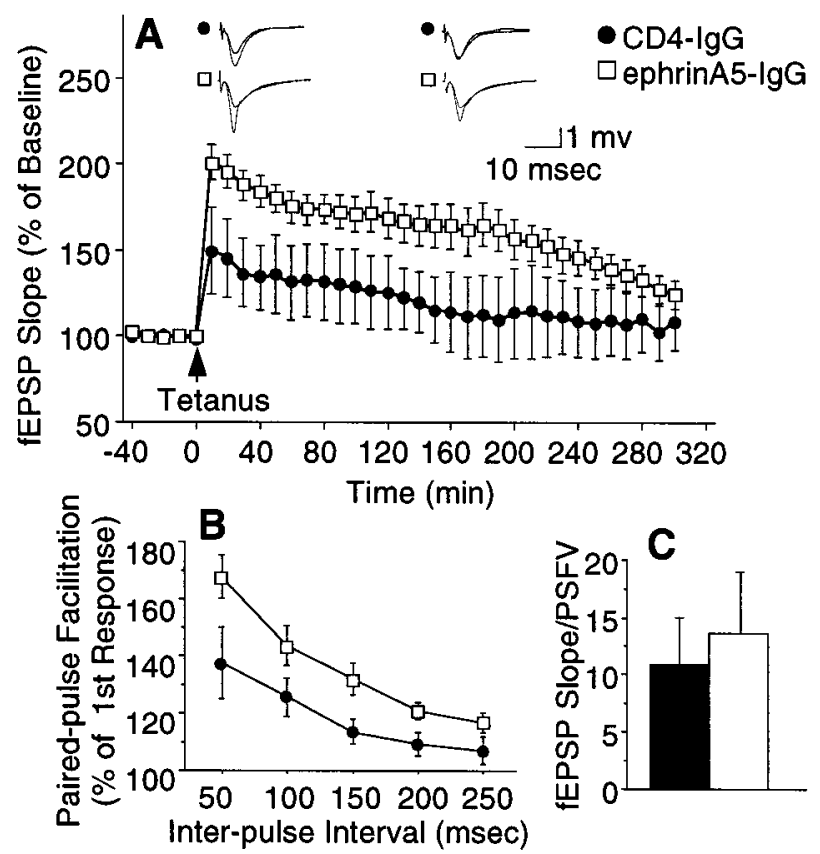

Figure 11. EphrinA5-IgG improves LTP and increases magnitude of PPF in hippocampal slices prepared from DBA/2. A, Field EPSP expressed as percentage of baseline. Twenty sequential responses were averaged and plotted as one point. ANOVA, including data from all time points, revealed an immunoadhesin effect that bordered significance $\left(F_{(1,12)}=4.23 ; p=0.06\right)$, whereas Tukey's HSD test showed that the groups were significantly different $(p<0.05)$ up to 260 min posttetanization. Representative traces before and after tetanization at corresponding time points, as indicated, are also shown. $B$, PPF varied as a function of immunoadhesin treatment $\left(F_{(1,21)}=6.189 ; p<0.03\right)$, and no significant immunoadhesin $\times$ interval interaction $\left(F_{(4,84)}=1.654 ; p>\right.$ $0.16)$ was seen. $C$, No significant differences were found in basal synaptic transmission between ephrinA5-IgG-inf used (white bar) and CD4-IgGinf used (black bar) mice $(t=0.416 ; \mathrm{df}=18 ; p>0.68)$. Estimation of basal synaptic transmission by I/O characteristics using Michaelis-Menten sigmoid curve fit revealed no significant differences (CD4-IgG, mean of $2.49 \pm 0.33$; ephrinA5-IgG, mean of $2.80 \pm 0.97 ; p>0.70)$.

notion also supported by the lack of indication of altered performance factors detected in these tasks. We infer, therefore, that the observed behavioral changes were attributable to altered cognitive processes. Together, these results support a role for EphA in adult neural function associated with learning, one which can be augmented by ephrinA5-IgG and impaired by EphA5-IgG.

The potential neurobiological mechanism underlying the observed behavioral effects is speculative at this point. The recent observation showing that Eph receptors and their ephrin ligands contain PDZ recognition motifs and are bound and clustered by PDZ proteins at presynaptic and postsynaptic sites of neuronal synapses in vitro suggests that Eph receptors may mediate synaptic plasticity (Hsueh and Sheng, 1998; Torres et al., 1998). In vitro, acute application of EphA5-IgG (EphA antagonist) and ephrinA5-IgG (agonist) has also been shown to influence parameters of synaptic plasticity on the hippocampal slice, implying the functional relevance of EphA receptors (W.-Q. Gao et al., 1998). These suggestive findings are now confirmed by our present electrophysiological results. The Both our and W.-Q. Gao et al.'s (1998) results generally revealed an inhibitory role for EphA5IgG and a facilitatory effect of ephrinA5-IgG at the synaptic physiology level. W.-Q. Gao et al. (1998) found that application of

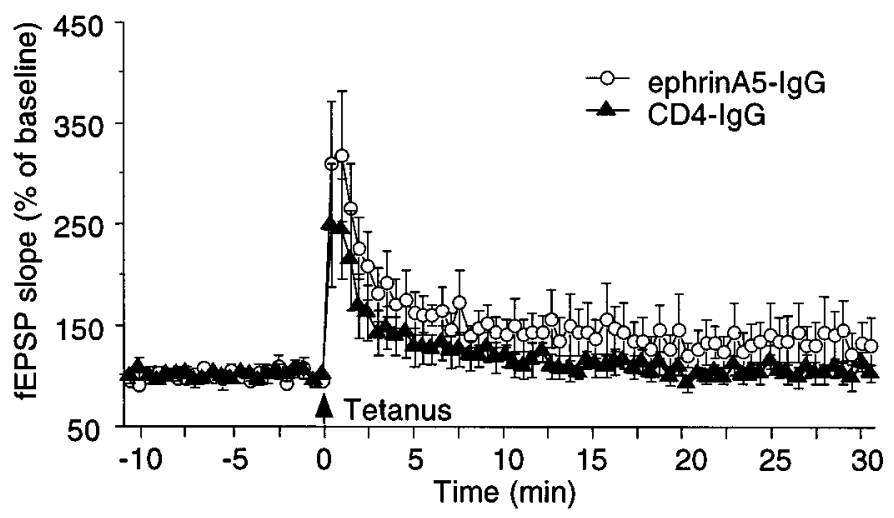

Figure 12. Chronic ephrinA5-IgG infusion leads to an apparent increase of LTP in hippocampal slices prepared from C57BL/6 mice. Individual responses measured once every $30 \mathrm{sec}$ are plotted. Open circles, EphrinA5-IgG infusion $(n=6)$; filled triangles, CD4-IgG inf usion $(n=6)$. One hippocampal slice per experimental animal was tested; thus, $n$ represents the number of animals analyzed. Error bars indicate SE. ANOVA revealed that the apparent immunoadhesin effect was not significant $\left(F_{(1,10)}=1.973 ; p=0.190\right)$ nor was the time $\times$ immunoadhesin interaction significant $\left(F_{(60,600)}=0.447 ; p>0.50\right)$.

ephrinA5-IgG impaired PPF, probably as a result of a facilitatory effect of ephrinA5-IgG on neurotransmitter release leading to depletion of synaptic vesicles, as these authors suggested based on other studies (Manabe et al., 1993). This suggestion was in accordance with another observation made by W.-Q. Gao et al. (1998) showing facilitated baseline synaptic responses to ephrinA5-IgG. In our present study, we could not measure preimmunoadhesin application baseline responses and thus were unable to compare the effects of ephrinA5-IgG treatment to it. However, unlike W.-Q. Gao et al. (1998), we detected increased PPF in slices taken from hippocampi chronically infused with ephrinA5-IgG. The apparent discrepancy may be explained by a common underlying mechanism, namely, facilitated neurotransmitter release. Although it has been shown that acutely enhanced neurotransmitter release leads to decreased PPF (Manabe et al., 1993), a correlation between chronic enhancement of neurotransmitter release and enhanced PPF has also been demonstrated (Geppert et al., 1997). Furthermore, W.-Q. Gao et al. (1998) could detect impaired LTP in EphA5-IgG-treated slices, similar to our findings, but they could not demonstrate improved LTP in slices bathed in ephrinA5-IgG, whereas we found increased LTP in response to chronic ephrinA5-IgG infusion. This apparent discrepancy again may reflect differences in the mode of application, i.e., acute versus chronic infusion, of the immunoadhesins leading to differential effects of EphA receptor function on timedependent synaptic processes. These processes may involve cytostructural mechanisms in which EphA receptors have been suggested to play roles.

EphA receptors may interact with a number of proteins through their PDZ binding domains that mediate cytoskeletal processes (Torres et al., 1998) and potentially affect a range of subcellular mechanisms influencing synaptic transmission and/or plasticity. Such mechanisms may include, for example, the trafficking and docking of presynaptic vesicles (Calakos and Scheller, 1996), the clustering of neurotransmitter receptors, e.g., AMPA-R and NMDA-R (Allison et al., 1998), and the formation of "perforated" synapses associated with LTP (Geinisman et al., 1991, 1993; Edwards, 1995). Importantly, EphA5 receptor has been shown to mediate actin polymerization, and its activation by 
administration of ephrinA5-IgG leads to actin depolymerization and axonal growth cone collapse in neuronal cell cultures and cortical explants (Meima et al., 1997). Actin is a crucial component of the cytoskeleton present in presynaptic and postsynaptic terminals (Fifkova and Delay, 1982; Landis and Reese, 1983; Cohen et al., 1985). It has been shown to be associated with structural changes underlying synaptic plasticity (Westrum et al., 1980; Fifkova and Delay, 1982; Landis and Reese, 1983; Hayashi et al., 1996) affecting both presynaptic and postsynaptic mechanisms, including paired pulse facilitation and LTP (Kim and Lisman, 1999). In the latter study, phalloidin, an actin filament stabilizing agent, when applied postsynaptically, significantly impaired LTP. Remarkably, and perhaps consistent with this observation, our results showed that application of the EphA agonist ephrinA5-IgG, which destabilizes actin filaments (Meima et al., 1997), has the opposite effect, i.e. it improves LTP. Thus, it is possible that EphA receptor activation mobilizes the synapse by destabilizing actin filaments and thus allows it to undergo structural modifications necessary for plastic changes to take place, a suggestion that will need to be confirmed by detailed electronmicroscopic or confocal analyses.

The possibility that EphA receptors play roles in cytostructural processes is consistent with the changes we observed in the expression of tubulin gene in response to EphA5-IgG or ephrinA5-IgG treatment. Our results suggested that tubulin, a component of the cytoskeleton, was overexpressed in response to EphA receptor inactivation and was underexpressed in response to receptor activation in the adult mouse hippocampus, findings compatible with the known arresting effects of ephrin-A ligands on axonal and dendritic growth during CNS development (Winslow et al., 1995; Meima et al., 1997; Frisén et al., 1998). In the adult brain in which major developmental alterations do not take place, transcriptional regulation of tubulin and perhaps other genes of cytoskeletal proteins may subserve the development of new or altered synaptic connections, i.e., neural plasticity. Based on our findings, we suggest that tubulin, perhaps mediating axonal and dendritic transport, or microstructural localization of gene products required for synaptic remodeling, plays a role in such plasticity and in turn learning as assumed previously by Rose and associates (Mileusnic et al., 1980; Scholey et al., 1992; Rose, 1993).

An intriguing aspect of our findings is the observed cognitive improvement and facilitated LTP both induced by ephrinA5-IgG. LTP has been suggested to be a cellular mechanism that underlies learning and memory (Bliss and Collingridge, 1993) (but see Shors and Matzel, 1997), and, for example, numerous studies using gene targeting have shown an association between impaired LTP and impaired cognitive function in mice (for examples, see Gerlai, 1996a,c). However, the two mouse mutants in which chronically improved LTP has been observed [e.g., the GluR2 mutant (Jia et al., 1996) or the postsynaptic density-95 mutant (Migaud et al., 1998)] also exhibited impaired behavioral function (Gerlai et al., 1998a; Migaud et al., 1998). For instance, GluR2less neurons of the GluR2 mutant mice showed increased permeability to calcium, causing an increased calcium influx leading in turn to elevated LTP upon tetanic stimulation. Gerlai et al. (1998a), argued that the nonspecific nature of the facilitation of LTP led to impaired behavioral function because it decreased the signal-to-noise ratio of stimulus processing in the brain. Migaud et al. (1998) also concluded similarly and explained that a proper balance between LTP and long-term depression induction threshold must be maintained for the neurons to process information correctly. According to this argument, experimentally improved synaptic plasticity can lead to improved cognitive function only if it does not impair the specificity and selectivity of synaptic strengthening or weakening as defined by behaviorally relevant stimulus processing. Plausibly, EphA function may not influence which synaptic connections become strengthened or weakened but may facilitate the ensuing microstructural changes only after proper behavioral or electrophysiological stimulation has occurred. Although speculative at this point, if the working hypothesis that chronic facilitation of EphA function primes synapses for synapse-specific use-dependent modification is correct (for a conceptually similar hypothesis, see Abraham and Tate, 1997), EphA receptors may become an important therapeutic target for a number of human conditions in which cognitive function is affected.

Regardless of the precise identity of the molecular and neurobiological mechanisms, the present findings now have revealed a role for EphA receptor tyrosine kinases in cognitive function in the adult mammalian brain. These findings open an unexpected avenue into the functional analysis of this large receptor protein family and may lead to novel targets for therapeutic intervention in human brain and behavioral disorders.

\section{REFERENCES}

Abeliovich A, Paylor R, Chen C, Krim J, Wehner J, Tonegawa S (1993) PKC $\gamma$ mutant mice exhibit mild deficits in spatial and contextual learning. Cell 75:1263-1271.

Abraham WC, Tate WP (1997) Metaplasticity: a new vista across the field of synaptic plasticity. Prog Neurobiol 52:303-323.

Aiba A, Chen C, Herrup K, Rosenmund C, Stevens C, Tonegawa S (1994) Reduced hippocampal long-term potentiation and contextspecific deficit in associative learning in mGluR1 mutant mice. Cell 79:365-375.

Allison DW, Gelfand VI, Craig AM (1998) Role of actin in anchoring postsynaptic receptors in cultured hippocampal neurons: differential attachment of NMDA versus AMPA receptors. J Neurosci 18:2423-2436.

Bach ME, Hawkins RD, Osman M, Kandel ER, Mayford M (1995) Impairment of spatial but not contextual memory in CaMKII mutant mice with a selective loss of hippocampal LTP in the range of the theta frequency. Cell 81:905-915.

Blanchard RJ, Blanchard DC (1969) Crouching as an index of fear. J Comp Physiol Psychol 81:281-290.

Bliss TVP, Collingridge GL (1993) A synaptic model of memory: longterm potentiation in the hippocampus. Nature 361:34-39.

Calakos N, Scheller RH (1996) Synaptic vesicle biogenesis, docking, and fusion: a molecular description. Physiol Rev 76:1-29.

Chamow SM, Ashkenazi A (1996) Immunoadhesins: principles and applications. Trends Biotechnol 14:52-60.

Cohen RS, Chung SK, Pfaff DW (1985) Immunocytochemical localization of actin in dendritic spines of the cerebral cortex using colloidal gold as a probe. Cell Mol Neurobiol 5:271-284.

Crusio WE, Bertholet JY, Schwegler H (1990) No correlations between spatial and non-spatial reference memory in a T-maze task and hippocampal mossy fibre distribution in the mouse. Behav Brain Res 41:251-259.

Douglas RJ (1990) Spontaneous alternation behavior and the brain. In: Spontaneous alternation behavior (Denber WN, Richman LL, eds), pp 73-109. New York: Springer.

Drescher U, Kremoser C, Handwerker C, Loschinger J, Noda M, Bonhoeffer F (1995) In vitro guidance of retinal ganglion cell axons by RAGS, a $25 \mathrm{kDa}$ tectal protein related to ligands for Eph receptor tyrosine kinases. Cell 82:359-370.

Edwards FA (1995) LTP-a structural model to explain the inconsistencies. Trends Neurosci 18:250-255.

Fifkova E, Delay RJ (1982) Cytoplasmic actin in neuronal processes as a possible mediator of synaptic plasticity. J Cell Biol 95:345-350.

Flanagan JG, Vanderhaeghen P (1998) The ephrins and Eph receptors in neural development. Annu Rev Neurosci 21:309-345. 
Friedman GC, O'Leary DDM (1996) Eph receptor tyrosine kinases and their ligands in neural development. Curr Opin Neurobiol 6:127-133.

Frisén J, Yates PA, McLaughlin T, Friedman GC, O'Leary DDM, Barbacid M (1998) Ephrin-A5 (AL-1/RAGS) is essential for proper retinal axon guidance and topographic mapping in the mammalian visual system. Neuron 20:235-243.

Gao PP, Zhang JH, Yokoyama M, Racey B, Dreyfus CF, Black IB, Zhou $\mathrm{R}$ (1996) Regulation of topographic projection in the brain: Elf-1 in the hippocamposeptal system. Proc Natl Acad Sci USA 93:11161-11166.

Gao PP, Yue Y, Zhang JH, Cerretti DP, Levitt P, Zhou R (1998) Regulation of thalamic neurite outgrowth by the Eph ligand ephrin-A5: implications in the development of thalamocortical projections. Proc Natl Acad Sci USA 95:5329-5334.

Gao W-Q, Shinsky N, Armanini MP, Moran P, Zheng JL, MendozaRamirez JL, Phillip HS, Winslo JW, Cara IW (1998) Regulation of hippocampal synaptic plasticity by the tyrosine kinase receptor, REK7/ EphA5, and its ligand, AL-1/Ephrin-A5. Mol Cell Neurosci 11:247-259.

Geinisman Y, de Toledo-Morrell L, Morrell F (1991) Induction of longterm potentiation is associated with an increase in the number of axospinous synapses with segmented postsynaptic densities. Brain Res 566:77-88.

Geinisman Y, de Toledo-Morrell L, Morrell F, Heller RE, Rossi M, Parshall RF (1993) Structural synaptic correlate of long-term potentiation: formation of axospinous synapses with multiple, completely partitioned transmission zones. Hippocampus 3:435-446.

Geppert M, Goda Y, Stevens CF, Südhof TC (1997) The small GTPbinding protein Rab3A regulates a late step in synaptic vesicle fusion. Nature 387:810-814.

Gerlai R (1996a) Gene targeting studies of mammalian behavior: is it the mutation or the background genotype? Trends Neurosci 19:177-181.

Gerlai R (1996b) Gene targeting in neuroscience: the systemic approach. Trends Neurosci 19:188-189.

Gerlai R (1996c) Molecular genetic analysis of mammalian behavior and brain processes: caveats and perspectives. Semin Neurosci 8:153-161.

Gerlai R (1998a) A new continuous alternation task in T-maze detects hippocampal dysfunction in mice: a strain comparison and lesion study. Behav Brain Res 95:91-101.

Gerlai R (1998b) Contextual learning and cue association in fear conditioning in mice: a strain comparison and a lesion study. Behav Brain Res 95:191-203.

Gerlai R, Clayton NS (1999) Analysing hippocampal function in transgenic mice: an ethological perspective. Trends Neurosci 22:47-51.

Gerlai R, Friend W, Becker L, O'Hanlon R, Marks A, Roder J (1993) Female transgenic mice carrying the human gene for $\mathrm{S} 100 \beta$ are hyperactive. Behav Brain Res 55:51-59.

Gerlai R, Henderson JT, Roder JC, Jia Z (1998a) Multiple behavioral anomalies in GluR2 mutant mice exhibiting enhanced LTP. Behav Brain Res 95:37-45.

Gerlai R, Cairns B, Van Bruggen N, Moran P, Shih A, Sauer H, Phillips HS, Caras I, Winslow J (1998b) Protein targeting in the analysis of learning and memory: a potential alternative approach to gene targeting. Exp Brain Res 123:24-35.

Gibson UEM, Heid CA, Willimas PM (1996) A novel method for real time quantitative RT-PCR. Genome Res 6:995-1001.

Hayashi K, Ishikawa R, Ye LH, He XL, Takata K, Kohama K, Shirao T (1996) Modulatory role of drebrin on the cytoskeleton within dendritic spines in the rat cerebral cortex. J Neurosci 16:7161-7170.

Heid AC, Stevens J, Livak KJ, Williams PM (1996) Real time quantitative PCR. Genome Res 6:986-994.

Hsueh Y-P, Sheng M (1998) Eph receptors, ephrins, and PDZs gather in neuronal synapses. Neuron 21:1227-1229.

Jia Z, Agopyan N, Miu P, Xiong Z, Henderson J, Gerlai R, Taverna F, MacDonald J, Carlen P, Abramow-Newerly W, Roder J (1996) Enhanced LTP in the absence of GluR2. Neuron 17:945-956.

Kim CH, Lisman JE (1999) A role of actin filament in synaptic transmission and long-term potentiation. J Neurosci 19:4314-4324.

Kim JJ, Fanselow MS (1992) Modality-specific retrograde amnesia of fear. Science 256:675-677.

Landis DM, Reese TS (1983) Cytoplasmic organization in cerebellar dendritic spines. J Cell Biol 97:1169-1178.

Lorenzini CA, Baldi E, Bucherelli C, Sacchetti B, Tassoni G (1996a) Role of dorsal hippocampus in acquisition, consolidation and retrieval of rat's passive avoidance response: a tetrodotoxin functional inactivation study. Brain Res 730:32-39.

Lorenzini CA, Baldi E, Bucherelli C, Sacchetti B, Tassoni G (1996b) Role of ventral hippocampus in acquisition, consolidation and retrieval of rat's passive avoidance response memory trace. Brain Res 730:32-39.

Manabe T, Wyllie DJ, Perkel DJ, Nicoll RA (1993) Modulation of synaptic transmission and long-term potentiation: effects on paired pulse facilitation and EPSC variance in the CA1 region of the hippocampus. J Neurophysiol 70:1451-1459.

Matsuyama S, Namgung U, Routtenberg A (1997) Long-term potentiation persistence greater in $\mathrm{C} 57 \mathrm{BL} / 6$ than $\mathrm{DBA} / 2$ mice: predicted on basis of protein kinase $\mathrm{C}$ levels and learning performance. Brain Res 763:127-130.

Meima L, Kljavin IJ, Shih A, Winslow JW, Caras IW (1997) AL-1induced growth cone collapse of rat cortical neurons is correlated with REK7 expression and rearrangement of the actin cytoskeleton. Eur J Neurosci 9:177-188.

Melton DA, Krieg PA, Rebagliati MR, Maniatis T, Zinn K, Green MR (1984) Efficient in vitro synthesis of biologically active RNA and RNA hybridization probes from plasmids containing a bacteriophage SP6 promoter. Nucleic Acids Res 12:7035-7056.

Migaud M, Charlesworth P, Dempste, M, Webster LC, Watabe AM, Makhinson M, He Y, Ramsay MF, Morris RG, Morrison JH, O’Dell TJ, Grant SG (1998) Enhanced long-term potentiation and impaired learning in mice with mutant postsynaptic density-95 protein. Nature 396:433-439.

Mileusnic R, Rose SPR, Tillson P (1980) Passive avoidance learning results in region-specific changes in concentration of and incorporation into colchicine-binding proteins in the chick forebrain. J Neurochem 34:1007-1015.

Moser M-B, Moser EI, Forrest E, Andersen P, Morris RGM (1995) Spatial learning with a minislab in the dorsal hippocampus. Proc Natl Acad Sci USA 92:9697-9701.

Orioli D, Klein R (1997) The Eph receptor family: axonal guidance by contact repulsion. Trends Genet 13:354-360.

Paylor R, Tracy R, Wehner J, Rudy JW (1994) DBA/2 and C57BL/6 mice differ in contextual fear but not auditory fear conditioning. Behav Neurosci 108:810-817.

Phillips HS, Hains JM, Laramee GR, Rosenthal A, Winslow JW (1990) Widespread expression of BDNF but not NT-3 by target areas of basal forebrain cholinergic neurons. Science 250:290-294.

Phillips RG, LeDoux JE (1992) Differential contribution of amygdala and hippocampus to cued and contextual fear conditioning. Behav Neurosci 106:274-285.

Quinlan EM, Halpain S (1996) Postsynaptic mechanisms for bidirectional control of MAP2 phosphorylation by glutamate receptors. Neuron $16: 357-368$.

Rose PRS (1993) Synaptic plasticity, learning and memory. In: Synaptic plasticity (Baudry M, Thompson RF, Davis JL, eds), pp 209-229. Cambridge, MA: MIT.

Scholey A, Bullock S, Rose SPR (1992) Passive avoidance learning in the young chick results in time- and locus-specific elevations of alphatubulin immunoreactivity. Neurochem Int 21:343-350.

Shors TJ, Matzel LD (1997) Long-term potentiation: what's learning got to do with it? Behav Brain Sci 20:597-655.

Silva AJ, Rosahl TW, Chapman PF, Marowitz Z, Friedman E, Frankland PW, Cestari V, Cioffi D, Südhof TC, Bourtchuladze R (1996) Impaired learning in mice with abnormal short-lived plasticity. Curr Biol 6:1509-1518.

Torres R, Firestein BL, Dong H, Staudinger J, Olson EN, Huganir RL, Bredt DS, Gale NW, Yancopoulos GD (1998) PDZ proteins bind, cluster, and synaptically colocalize with Eph receptors and their ephrin ligands. Neuron 21:1453-1463.

Westrum LE, Jones DH, Gray EG, Barron J (1980) Microtubules, dendritic spines and spine apparatuses. Cell Tissue Res 208:171-181.

Winslow JW, Moran P, Valverde J, Shih A, Yuan JQ, Wong SC, Tsai SP, Goddard A, Henzel WJ, Hefti F, Beck KD, Caras IW (1995) Cloning of AL-1, a ligand for an eph-related tyrosine kinase receptor involved in axon bundle formation. Neuron 14:973-981.

Zhang J-H, Cerretti D, Yu T, Flanagan JG, Zhou R (1996) Detection of ligands in regions anatomically connected to neurons expressing the eph receptor Bsk: potential roles in neuron-target interaction. J Neurosci 16:7182-7192.

Zhou R (1997) Regulation of topographic projection by the Eph family receptor Bsk (EphA5) and its ligands. Cell Tissue Res 290:251-259. 